\title{
TMT Attention to Innovation of Organizations Influence the Organization Innovation Activities: Moderating Role of Corporate Governance
}

\author{
Muhammad Imran Nazir \\ PhD Scholar (Finance), School of Finance \\ Zhongnan University of Economics and Law, China \\ E-mail: imran.n13@outlook.com \\ Muhammad Rizwan Nazir \\ PhD Scholar (Finance), School of Finance \\ Zhongnan University of Economics and Law, China
}

Ifran Khan

MS Scholar (Finance), IFAS

Xiamen University, China

Faryal

PMAS Arid Agriculture University Rawalpindi, Pakistan

Received: March 15, 2018

Accepted: March 25, 2018

Published: March 28, 2018

doi:10.5296/ijafr.v8i1.12907

URL: https://doi.org/10.5296/ijafr.v8i1.12907

\begin{abstract}
This study examines the TMT attention to innovation influences an organizations innovation activities. The results show that the influence of executive attention to innovation on organizations innovation activities is moderated by the characteristics of corporate governance. This study develop and test the hypotheses imitative from the expectation of firm
\end{abstract}


level data covering the period of 2012-2016. The result shows that TMTAI is positively related with an organization's patent application, and that the positive association is stronger when an organizations is a state owned, has a large members of the board, and has a few independent directors.

Keywords: Organization innovation, Corporate governance, TMTAI

\section{Introduction}

The top administrators are supposed to make a huge difference in influencing the path and results of an organization innovation, such as building and handling an innovation culture, development an innovative atmosphere, and manipulative pro-innovation strategies (Chatman and Cha, 2003). Wu, Levitas and Priem (2005) determine that executive tenancy is linked to an organization's patent approvals. The top managers might apply a distinction of influence on their organizations through developed economies (Crossland and Hambrick, 2011), study on how corporate managers in emerging markets influence the firm innovations are exceptional (Chen, Tjosvold and Liu, 2006). Additional, no research has scrutinized the influence of administrative attention and innovation (Yang et al., 2011). So after that the Chinese government is to introduce market-based transactional system so as to advocate innovation (Yang et al., 2012).

The innovation is mainly addressed on management attention (Van de Ven, 1986), upper managers of different organizations might apportion their funds and attention to different regions (Hambrick et al., 2005). The top managers frequently have inadequately attentional funds (Dutton and Ashford, 1993), they need to direct their attention to the most essential plan ingenuities (Kaplan, 2008). The recently how TMT attention effects organization innovation has expanded momentum (Kaplan, 2011). Therefore, some of the managers might be inhibited by external and internal powers and then tend to follow the old plan while other administrators might attention to changes and be innovative (Kaplan, 2008). The position might be aggravated in different economies with vigorous institutional atmospheres where substantial transition and marvelous deviations have happened over the past periods. The environmental enthusiasm has constructed institutional heterogeneity that can both limit or boost the impacts of upper management team's attention to innovation. Consequently, it is stimulating to research if the attention-innovation association exists.

Additionally, we study the eventuality role of corporate governance on the attention-innovation association. The different researchers contended that even though the upper managers issue to an organization's policies and outcomes (Thomas, 1988; Wu et al., 2005), they succeed with restraints that frequently outcome from managerial features, internal powers and task atmosphere (Boyd and Gove, 2006). Very limited empirical works have made the association among upper managers and organization's innovation. Chen et al., (2006) found that the leaders values are positive allied to the innovation. Therefore, such empirical works fail to deliberate those important factors of contingency (Yang et al., 2012). The constrictions are entrenched in situations in that emerging economies can be relatively diverse than those of developed economies in different aspects including political, governmental, culture, and economic systems. The Chinese organizations might be subject to 
different level of controls initiated from task atmosphere and government interventions. The government administrations might deliver little legal shelter on contravention of innovation, which might impede an organizations striving (Tan, 2001). The government organizations might also interfere an organization's decision making through corporate governance like the composition of the board, the separation of corporate governance configuration "argumentative issue" in the conversion to a market-based economy (Cheung et al., 2010). Some of the inimitable corporate governance contrivances such as the two-tier board structure intended to enhance an organization's smooth plan operation and performance might instead inhibit a firm's innovative results by diverting the manager's attention to essential innovative ingenuities. Although inspecting the moderating effect of corporate governance in China, we enhance supervisory attention research in that we institute the boundary of when TMTAI might be more effective in augmenting innovative actions.

The target of this research at different contributions to the literature with this current research. This study builds on the administrative attention research and prolongs the stream of research to research organizations in China, an emerging economy (Kaplan, 2011). This paper also deliberates not only the association among attention and innovative results, but also the contingency effect of corporate governance mechanism on innovations. After all, the very few works that scrutinize the managers and innovations conduct survey research defining the innovations as innovativeness. The dependent variable measures innovative actions as patent applications that can invite replication empirical research work.

\section{Literature Review}

The management researchers have long acknowledged that attention is a limited cognitive resource (Dutton and Ashford, 1993; Parasuraman 1998). It is believed that the job demand of upper managers is relatively complex and stimulating so the inadequacy of cognitive funds is fully exposed, resulting in information overwork for the job of upper management. The nature of their job demand, upper managers are believed to resort to foregoing routines, the procedure of concerning raw data to pre-existing plans and world assessments stored in their retentions, to condense the cognitive pressure and enhance the efficiency in information processing (Hambrick et al., 2005).

The CEO's attentional concentration on new diverse technologies affects the patent granted (a measure of the innovation) to organizations for a period of twenty years in technology industries (Kaplan, Cognition, capabilities, and incentives: Assessing firm response to the fiber-optic revolution, 2008). The airlines industry after the deregulation, Cho and Hambrick (2006) advocated that the airlines organizations with upper managers paying more concentration to entrepreneurial matters are more probable to undertake entrepreneurial actions such as new directions of different flights. Yadav et al., (2007) revealed that CEOs concentrating their attention on upcoming events and on different external issues in the financial industries lead to active implementation of internet-based technologies and services in their financial institutions. Nadkarni and Narayanan (2007) proposed that intricate plans empower the managers to construct a wide-ranging attentiveness of new opportunities and hereafter to develop new funds and to change their competitive attitude rapidly by stimulating 


\section{MInstitute Macrothink $_{\text {Int }}^{\text {Intis }}$}

International Journal of Accounting and Financial Reporting ISSN 2162-3082

better implication of continuously shifting the competitor's moves. Li, et al. (2013) suggested that assortment in territory foundations searched by TMTs in publicly organizations enables different new product innovation on their firms. Additionally, it has been originate that the concentration of exploration for innovation incentives by top managers restrains the association among the assortment of search and the distance of search territory. The above brief review of the past empirical literature suggests that the TMT attention literature is still small and developing. There has not been much indication showing a direct influence of the TMT attention on an organization innovation. Also, how attention works together with other potential influences of organization innovation has been under examined.

The effects of TMTAI on the innovation activities of organizations might be tempered by the restraints that limit organization innovation actions stimulated by TMTAI. The preceding empirical literature on innovation recommends that in the environment of corporate governance might be a force that affects TMTAI on the organization innovation (Cheung, et al. 2010; Yang, Chi and Young 2011). This study focus on the internal corporate governance because it frequently applies direct and resilient influence on organization's policies and performance. The internal governance appliance manages an organizations through ownership, CEO duality, board of director's composition, and different committees (Cheung, Jiang, Limpaphayom, \& Lu, 2010). The internal governance in Chinese organizations has a few attributes that make the effect of corporate governance apparent. Firstly, different organizations are still owned and controlled by the state government. Secondly, the publically listed companies is required to maintain the certain proportions of the independent directors on the board. This obligation might affect the authority distribution between the members of the board and among board and the upper management teams. Thirdly, the organization might also maintain an administrative chairman is often the secretary of the organization and has power to influence the organization policies such as the human resources policies. The CEO duality in a state firms might play a more significant role in affecting the preference of upper management and consequently a firm's behavior strategy. The CEO duality of the particular organization might play an important role in affecting the inclination of the upper management teams and therefore an organization's performance and plans (Yang et al., 2011).

The conceptualization of consideration and attentional alignment in the previous empirical literature (Ocasio, 1997; Cho and Hambrick, 2006), we define the fundamental concept of this research, TMTAI, as the degree of attention that TMT of an organization pays to innovation incitements. The more the TMTAI, the more attention a TMT will give to innovation related matters, which usually include, but not limited to, the generation and conversation of new innovative ideas and knowledge, procedure of new product development, protection, and patent filling. The innovation and TMT empirical literature recommended that TMTAI might stimulus firm innovation actions in a different ways. Firstly, TMTAI directly affects the organization strategies on innovation and funds obligation to innovation. The managers paying more consideration to innovation are more probable to construct policies and procedures to encourage and institution innovation practices, due to their selective consideration to innovation merely imitates manager's confidence in innovation (Ocasio, 


\section{MInstitute Macrothink $^{m}$}

International Journal of Accounting and Financial Reporting ISSN 2162-3082

1997). Secondly, innovation inducements attractive consideration of top managers would be the noticeable and unusual matters captured by executive attention, which addresses structure violating inducements apparent by a manager. All of these stimuli's innovation will prompt managers to reconsideration their organizations position, and push them to make different changes. As a result, manager's artifact exclusive consideration to seizure novel innovation inducements are more probable to commit funds, exertions and consultants to innovation (Peeters and Potterie, 2006).

The state owned organizations are inimitable because they are owned partly by not pure rent pursuing financiers who care more about returns ( $\mathrm{Li}$ and Tang, 2010). In a many instances, government also used the state owned enterprises to ensure the application of national strategies to attain long-term macro-economic objectives, economic development schemes, and to pursue communal social goals (Lin, 2011). The managers in firms with state-ownership often perform conventionally to avoid the suspicions in the results of innovation that might endanger their career as state assistances. The TMT pass on their consideration of innovation to stakeholders, state representatives might change the consideration deliberately to keep the firm stay in course with the government's purposes. The consideration of TMT given to innovation will be tougher to renovate into actions of innovation in state owned organizations because of the interference of state custodian. In distinction, the preference for managers in private companies is wider than that of their state-owned complements. The managing for owners with prevail benefits in wealth growth, top managers of private companies are directly accountable for the results of their own procedure (Li and Tang, 2010). Their comportments would be more market-oriented and own interest driven, instead of being diplomatically engaged and publically driven. As a result of their consideration to innovation would have a better influence on the innovation actions undertaken by their organization.

The CEO duality means that the chairman of board and the CEO are hold by the same individual (Nazir, et al. 2016). The CEO duality is supposed to be another influential factor of board observing attention on the top management (Young, Stedham and Beekun, 2000), and therefore could be another moderating appliance of TMTAI - organization innovation connection. The dual nomination often rises the chance that TMT's insight and attention will be more prominent on an organization activities. The duality amalgamates power and creates a unity among two groups of top decision makers in organizations. It is easier to impulsion a top management team's assessment by the board when CEO is also in-charge of the board. The top managers might sell their consideration and innovation schedule easily to the board. The association among TMTAI and the organization innovation will be more apparent in the existing of CEO duality. Tuggle et al., (2010) determined that in the existing of CEO duality, board attention to observing decreases based on the transcription of board meetings.

The large boards can be expensive because larger boards rise the operational complication. The increases of the board size, agency problems in the board room rise simultaneously, therefore prominent to more director free-riding problems and internal conflicts directors. Eisenberg, Sundgren and Wells (1998) contended that when board size increases, co-ordination and communication problems become more extensive, instigating greater 
problems in a board functioning. In the case of Chinese firms, the board is normally extended to contain members with political connection. All of these board members do not have specialized expertise and capabilities, and are "more of a decorative division than an effective committee" (Yang et al., 2011). The more members of the board in Chinese firms, the more probably non-professional are sitting on the boards. When a board deficiencies in-depth business experiences, they are probably to accept and be in agreement with the information providing by TMTs. The inclination more deteriorates the large board's capability to monitor the cognitive effects of top managers. The TMTAI will be more probably to leave mark on a firm innovation when an organization has a large board member. Therefore, the TMT is supervised by a small board, members of the board inspect more closely the decisions made by the TMT. The risky investment such as those into innovation ingenuities are more probably to be confronted by the smaller boards.

The magnitude a TMT's decision can be transformed into firm action is basically determined by a power play among the TMT and its observing board. The acceptability of board power might be expressively counteracted when a board cannot stay independent from the top manager's (Westphal and Zajac, 1995). The more independent member of a board is the more probable that perception and consideration of TMTs resultant in risk changes such as innovation will be adequately scrutinized. The independent directors who do not hold administrative positions in the firm where they serve, give out indication about the circulation of power as to monitoring over the decision making of the board and the configuration of interests among managers and owners (Jaskiewicz and Klein, 2007; Liang et al., 2012). Though, the empirical literature in this domain is unclear as to the directions that independent directors will impulsion the organizations to go using their attention concerning innovations. Some contended that independent directors are short-term gain seekers who tend to highlight the financial control and have a blinkered viewpoint of the organization innovation. If the independent directors are observed as short-term assistance seekers, they will be improbable to escalate and be able to understand the innovation matters appeared by the top managers. Therefore, the other empirical researchers contended that independent directors, particularly representatives from organizations, look for long term profits and might seek out investment in organizations that are integrally more innovation. The shareholders taking a long term view of business will embolden attention to innovation and change and are amenable to ideas of change and innovation. After all, from an agency perception, the influence of TMTAI on organization innovation is probably to be supported with the presence of independent directors.

$H_{1}$ : TMTAI has positive influence on an organization innovation.

$\mathrm{H}_{2}$ : The positive influence of TMTAI on organization innovation actions will be stronger in non-state owned organizations.

$\mathrm{H}_{3}$ : The CEO duality positively moderates the relationship among TMTAI and organization innovation activities.

$H_{4}$ : The larger the board of directors, the positive influence of TMTAI on organization innovation activities. 
$H_{5}$ : The positive influence of TMTAI on organization innovation will become weaker as the independence of board increases.

\section{Data and Methodology}

The sample consists of the manufacturing and technology organizations listed on the Shanghai Stock Exchange, China for the time period 2012-2016. We have selected the sample from publicly listed organizations for the reason that of the market capitalization and the top firms in China. We have collect data on 40 firms for a 5 years' time period and the main data comes from the China Stock Market \& Accounting Research (CSMAR) data base, DataStream data base, State Intellectual Property Office of the People's Republic of China, and also World Bank.

This study is used the number of patent applications as the measure of the innovation (Yang and Kuo, 2008). The patent application designate more of managerial activities while patent approvals can be the outcome of managerial exertions and it can also outcome from the governmental rules (Wu et al., 2005). Our focus of this study is innovation actions that the managers pursue, patent applications deem to be more proper than number of patents granted. We counted patent applications filed by an organizations each year over a five-year period from 2012 to 2016 . Then matched that with the explanatory variables, attention to innovation and corporate governance, and the other control variables. The dependent variable is molded one year after the independent variables. This one year lag permits enough time for TMTAI to be exhibited by their organization's innovation policies (Ahuja, 2000). This study is espoused archive-based approach to restructuring TMTAI in our sample by counting the words that apparent innovations in organizations annual reports to shareholders (McClelland et al., 2010). Some of the researchers have contended that the annual reports are often the work of public association section relatively than the replication of senior managers, interrogative the linking of content of annual reports and cognition to managers (Fiss and Zajac, 2006). We calculated TMTAI as the ratio between innovation-related words in organization annual reports and total words enclosed in those reports. The six main innovation interrelated words make the dictionary of words search for content analysis which is the same meaning in Chinese words: Intellectual property, patent protection, indigenous innovation, patent infringement,, technology innovation, and core technology.

The moderating variables which are used in this study as: board size is simply the number of board members in a particular board. Board independence is the proportion of independent director over the total directors. The state ownership was implicit as dichotomously, with 1 representing state ownership and 0 show otherwise. The CEO duality also used the dummy variable, with 1 show the CEO also chair of the board and 0 if the person was not. We also construct the corporate governance index which ultimately moderating effect with the TMTAI. We controlled for two indicators of organizations such as firm age and size. The firm age was measured as the number of years since the organizations primarily went publically. The firm size was measured as the natural log of the total assets. The debt ratio and firm's performance (measured as ROE) were also controlled. 


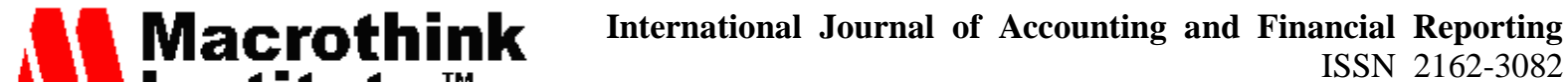 2018, Vol. 8, No. 1}

\section{Empirical Results and Conclusion}

Table 1 shows the descriptive statistics and correlation coefficients between all the variables. Table 2 reports the regression results estimations of TMTAI's influence on patent application. Model 1 in table 2 contains all the control and moderating variables. Model 2 in Table 2 assessments the main influence of the TMTAI on patent application. The coefficient of TMTAI variable is positive and significant. Therefore, the first hypothesis is supported. It means the stronger the TMT's attention to innovation, the more the number of organization patent application which they file. Then we include the moderating variables in model 3, 4, 5, and 6 to examine hypotheses 2, 3, 4, and 5. Model 3 inspects the influence of interaction among TMTAI and the all the corporate governance variables. The coefficient of interaction is positive and significant. Therefore, all the remaining hypothesis is supported. The first findings of direct influence of TMTAI on an organization innovation lends more sustenance for Van de Van's intuition that attention in an inadequate cognitive source of plans and should be accomplished efficiently to encourage innovation in organizations. The additional this source of attention is concentrating to innovation, rather than no other conflicting inducements such as firm politics and recompense, the more probable the organizations will be more innovative. The without adequate attention given to innovation substances, strategic ruling allied to innovation would not be established in a timely and suitable fashion, instigating the influence of upper managers on their organization's future into question. Consequently, the substantial and obstinate direct influence of TMTAI on firm patent application in this study puts theoretical estimate that upper manager's stimulus firm performance by attention (Hambrick, Finkelstein, \& Mooney, 2005). The external rationality of the influence of TMTAI on an organization innovation is established when this study is inspected together with the report (Kaplan, 2011).

Table 1. Descriptive Statistics and Correlation Matrix

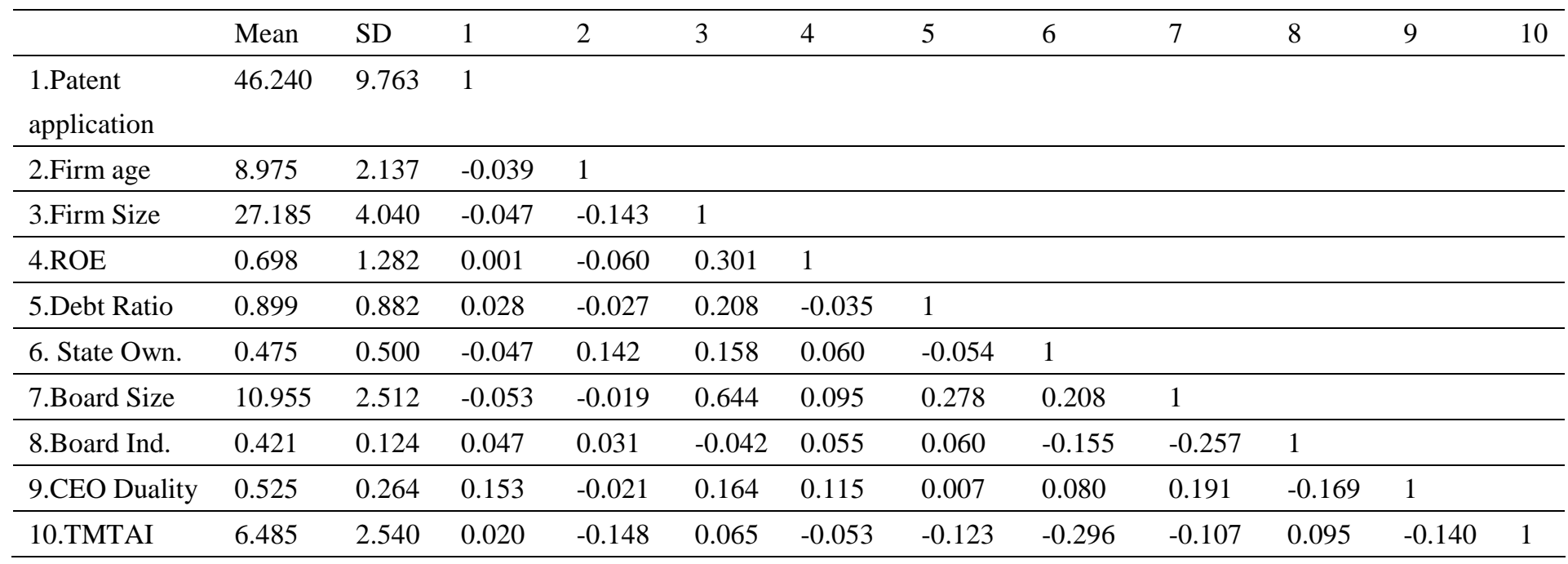




\section{Variable's Trend}

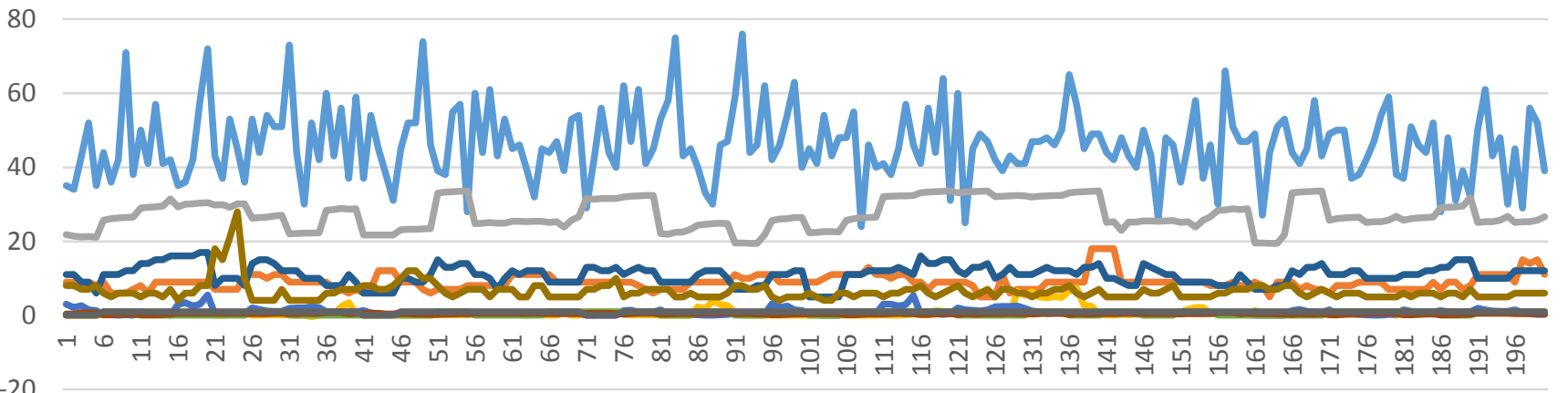
$-20$

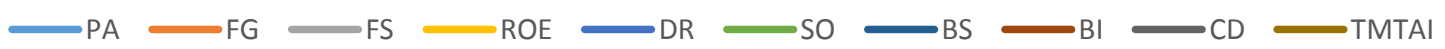

Figure 1. Variables Trend

Table 2. Regression Results

\begin{tabular}{|c|c|c|c|c|c|c|}
\hline Variables & Model 1 & Model 2 & Model 3 & Model 4 & Model 5 & Model 6 \\
\hline \multirow[t]{2}{*}{ Firm age } & $0.016 * * *$ & $0.010 * * *$ & $0.011 *$ & $0.022 * *$ & $0.019 * *$ & $0.013 *$ \\
\hline & $(0.002)$ & $(0.001)$ & $(0.000)$ & $(0.011)$ & $(0.010)$ & $(0.000)$ \\
\hline \multirow[t]{2}{*}{ Firm Size } & $0.621 * * *$ & $0.891 * * *$ & $0.521 * * *$ & $0.401 * *$ & $0.754 * * *$ & $0.421 * * *$ \\
\hline & $(0.004)$ & $(0.001)$ & $(0.003)$ & $(0.040)$ & $(0.001)$ & $(0.003)$ \\
\hline \multirow[t]{2}{*}{ ROE } & $1.089 * *$ & $1.091 * *$ & $1.159 * *$ & $1.071 * * *$ & 1.954 & 1.659 \\
\hline & $(0.031)$ & $(0.020)$ & $(0.041)$ & $(0.001)$ & $(0.256)$ & $(0.412)$ \\
\hline \multirow[t]{2}{*}{ Debt Ratio } & $-0.498 * * *$ & $-0.398 * *$ & $-0.510 * *$ & $-0.548 * *$ & -0.511 & $-0.621 * * *$ \\
\hline & $(0.005)$ & $(0.015)$ & $(0.040)$ & $(0.010)$ & $(0.117)$ & $(0.004)$ \\
\hline \multirow[t]{2}{*}{ State Own. } & $-0.178 * * *$ & $-0.219 * *$ & $-0.271 *$ & $-0.298 *$ & 0.211 & $-0.301 * * *$ \\
\hline & $(0.003)$ & $(0.014)$ & $(0.000)$ & $(0.000)$ & $(0.176)$ & $(0.007)$ \\
\hline \multirow[t]{2}{*}{ Board Size } & $-0.028 * *$ & $-0.023 * *$ & $-0.029 *$ & $-0.106 * *$ & $-0.231 * *$ & $-0.129 *$ \\
\hline & $(0.004)$ & $(0.014)$ & $(0.000)$ & $(0.030)$ & $(0.010)$ & $(0.000)$ \\
\hline \multirow[t]{2}{*}{ Board Ind. } & $0.619 * *$ & $0.832 * *$ & $1.811 * * *$ & $0.501 * *$ & $0.712 * * *$ & $1.341 *$ \\
\hline & $(0.001)$ & $(0.040)$ & $(0.001)$ & $(0.040)$ & $(0.006)$ & $(0.000)$ \\
\hline \multirow[t]{2}{*}{ CEO Duality } & $-0.081 * * *$ & -0.090 & $-0.051 *$ & $-0.108 * * *$ & $-0.129 * *$ & $-0.111 * * *$ \\
\hline & $(0.007)$ & $(0.117)$ & $(0.011)$ & $(0.006)$ & $(0.010)$ & $(0.001)$ \\
\hline \multirow[t]{2}{*}{ TMTAI } & & $79.260 * *$ & $89.021 * * *$ & $61.381 * *$ & $71.391 * * *$ & $85.029 *$ \\
\hline & & $(0.010)$ & $(0.001)$ & $(0.030)$ & $(0.002)$ & $(0.000)$ \\
\hline TMTAI & & & $55.761 * *$ & & & \\
\hline *State Own. & & & $(0.045)$ & & & \\
\hline TMTAI & & & & $-0.129 * * *$ & & \\
\hline *Board Size & & & & $(0.007)$ & & \\
\hline TMTAI & & & & & $0.620 * *$ & \\
\hline *Board Ind. & & & & & $(0.030)$ & \\
\hline TMTAI & & & & & & 0.419 \\
\hline
\end{tabular}


*CEO Duality

$(0.211)$

\begin{tabular}{lllllll}
\hline Constant & $-20.309 *$ & $-17.421^{*}$ & $-15.419^{* * *}$ & $-21.612^{* *}$ & $-19.389 * * *$ & $-21.003 * *$ \\
& $(0.080)$ & $(0.091)$ & $(0.003)$ & $(0.005)$ & $(0.001)$ & $(0.040)$ \\
\hline Pseudo $\mathrm{R}^{2}$ & 0.390 & 0.290 & 0.310 & 0.291 & 0.259 & 0.229 \\
\hline
\end{tabular}

Note: $* * *, * *$ and $*$ are $1 \%, 5 \%$ and $10 \%$ of significant levels, respectively

This study determines that corporate governance mechanism amends the association among TMTAI and the organization innovation, although in more intricate ways that appear to imitate the nature of theories in this area. The agency theory specifically contends that concerns for agency problem normally make a board observer the actions of TMTs more efficiently (Fama and Jensen, 1983). Though, the empirical literature on agency theory is indistinct as to which direction the operative monitoring of board will guide TMTs towards with reverence to the recreation of risk. If the board is apparently risk-averse, it would contradict an inclination of organizations to transfer funds into risk taking activities such as innovation. On the other hand, if the board is risk-taking, as customary agency theory contends for institutional owners, it would impulse for more innovation so that an organizations can follow the long-term objectives. The results show that the state ownership impedes the innovation behavior of organizations by limiting the transfer of TMTAI to action. Therefore, the findings is in line with the view that the state government attempts to implementation their ownership control of organizations to pursue social and political objects such as employment by decreasing the risk-taking comportments of TMTs and organizations (Li and Tang, 2010). When the board attentiveness is examined through a different positions, such as independence of the board, we find that the results appear to controvert the prophecy that the interests of the shareholders are to pursue long-term profit aims. As the independent directors on a board increases in the organizations we experimented, TMTAI becomes progressively improbable to transfer into actions of innovation. The findings is consistent with the (Deutsch, 2005).

The board size exerts a negative impact on TMTAI's influence on an organization innovation. The result imparts support to the argument that large board is unproductive in performing the role of corporate governance due to its tougher for large board to coordinate and reach unanimity (Eisenberg et al., 1998). There is no statistically significant influence of the CEO duality on TMTAI-organizations associations. There is no significant impact of the CEO-Chair duality on TMTAI-firm in a dynamic innovation is indistinct. The conflicting to the argument elevated by the agency theory that CEOs will take benefit of duality role to pursue the self-interests of agent, a perception elevated by stewardship theory (Finkelstein and D'Aveni, 1994) contends that in a duality setting, CEOs might just as well as perform as a stewards to the principle and are apprehensive about the interests of shareholders. We consider that the inimitable condition confronted by an organizations in our sample look to inflict a strong demand for stewardship role of CEOs in CEO duality setting. According to 


\section{$\Lambda$ Macrothink}

International Journal of Accounting and Financial Reporting ISSN 2162-3082

Young et al., (2000), corporate governance in impermanent economies is categorized by attentiveness of ownership.

This research will be supportive to the further researchers as it provided them with good theoretic implications of all variables under this study in the context of innovation. Further research can examination by containing the role of the more other proxies of innovation to measure its influence on the perspective of an organization.

\section{References}

Ahuja, G. (2000). Collaboration networks, structural holes, and innovation: A longitudinal study. Administrative Science Quarterly, 45(3), 425-455. https://doi.org/10.2307/2667105

Boyd, B., \& Gove, S. (2006). Managerial constraint: The intersection between organizational task environment and discretion. In David J. Ketchen, \& Donald D. Bergh (Eds.), 3 research methodology in strategy and management (Vol. 3., pp. 57-95). Emerald Group Publishing Limited. https://doi.org/10.1016/S1479-8387(06)03005-0

Chatman, J., \& Cha, S. (2003). Leading by leveraging culture. California Management Review, 45(4), 20-34. https://doi.org/10.2307/41166186

Chen, G., Tjosvold, D., \& Liu, C. (2006). Cooperative goals and leader people and productivity values: Their contribution to top management teams in China. Journal of Management Studies, 43(5), 1177-1200. https://doi.org/10.1111/j.1467-6486.2006.00633.x

Cheung, Y., Jiang, Limpaphayom, P., \& Lu, T. (2010). Corporate governance in China: A step forward. European Financial Management, 16(1), 94-123. https://doi.org/10.1111/j.1468-036X.2008.00446.x

Cho, T., \& Hambrick, D. (2006). Attention as the mediator between top management team characteristics and strategic change: The case of airline deregulation. Organization Science, 17, 453-469. https://doi.org/10.1287/orsc.1060.0192

Crossland, C., \& Hambrick, D. (2011). Differences in managerial discretion across countries: How national-level institutions affect the degree to which CEOs matter. Strategic Management Journal, 32, 797-819. https://doi.org/10.1002/smj.913

Deutsch, Y. (2005). The impact of board composition on firms' critical decisions: A meta analytic review. Journal of Management, 31(3), 424-444. https://doi.org/10.1177/0149206304272185

Dutton, J., \& Ashford, S. (1993). Selling issues to top management. Academy of Management Review, 18(3), 397-428.

Eisenberg, T., Sundgren, S., \& Wells, M. (1998). Larger board size and decreasing firm value in small firms. Journal of Financial Economics, 48, 35-54. https://doi.org/10.1016/S0304-405X(98)00003-8

Fama, E., \& Jensen, M. (1983). Separation of ownership and control. Journal of Law and Economics, 26, 301-326. https://doi.org/10.1086/467037 


\section{Mll Macrothink}

International Journal of Accounting and Financial Reporting

ISSN 2162-3082 2018, Vol. 8, No. 1

Finkelstein, S., \& D'Aveni, R. (1994). CEO duality as a double-edged sword: How boards of directors balance entrenchment avoidance and unity of command. Academy of Management Journal, 37, 1079-1108. https://doi.org/10.2307/256667

Fiss, P., \& Zajac, E. (2006). The symbolic management of strategic change: Sensegiving via framing and decoupling. Academy of Management Journal, 49, 1173-1193. https://doi.org/10.5465/AMJ.2006.23478255

Hambrick, D., Finkelstein, S., \& Mooney, A. (2005). Executive job demands: New insights for explaining strategic decisions and leader behaviors. Academy of Management Review, 30(3), 472-491. https://doi.org/10.5465/AMR.2005.17293355

Jaskiewicz, P., \& Klein, S. (2007). The impact of goal alignment on board composition and board size in family business. Journal of Business Research, 60(10), 1080-1089. https://doi.org/10.1016/j.jbusres.2006.12.015

Kaplan, S. (2008). Cognition, capabilities, and incentives: Assessing firm response to the fiber-optic revolution. Academy of Management Journal, 51(4), 672-695.

Kaplan, S. (2011). Research in cognition and strategy: Reflections on two decades of progress and a look to the future. Journal of Management Studies, 48(3), 665-695. https://doi.org/10.1111/j.1467-6486.2010.00983.x

Li, J., \& Tang, Y. (2010). CEO Hubris and firm risk taking in China: The moderating role of managerial discretion. Academy of Management Journal, 53(1), 45-68. https://doi.org/10.5465/AMJ.2010.48036912

Li, Q., Maggitti, P., Smith, K., Telsluk, P., \& Katila, R. (2013). Top management attention to innovation: The role of search selection and intensity in new product introduction. Academy of Management Journal, 56(3), 893-916. https://doi.org/10.5465/amj.2010.0844

Liang, X., Liu, Y., Wu, S., \& Zhang, S. (2012). Fending knights or masked kings: Toward a theoretical framework of interim CEO succession. Corporate Governance, 12(3), 367-377. https://doi.org/10.1108/14720701211234618

Lin, N. (2011). Capitalism in China: A centrally managed capitalism (CMC) and its future. $\begin{array}{llll}\text { Management } \quad \text { and } & \text { Organization }\end{array}$ https://doi.org/10.1111/j.1740-8784.2010.00203.x

McClelland, P., Liang, X., \& Barker, V. (2010). CEO commitment to the status quo: Replication and extension using content analysis. Journal of Management, 36(5), 1251-1277. https://doi.org/10.1177/0149206309345019

Nadkarni, S., \& Narayanan, V. (2007). Strategic schemas, strategic flexibility, and firm performance: The moderating role of industry clockspeed. Strategic Management Journal, 28(3), 243-270. https://doi.org/10.1002/smj.576 


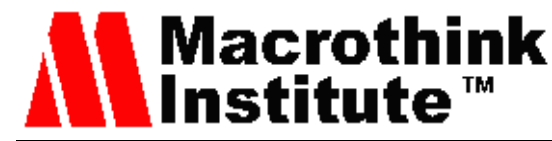

International Journal of Accounting and Financial Reporting ISSN 2162-3082

Nazir, M., Zulfiqar, M., Saeed, M., \& Habib, Y. (2016). The Influence of Board Characteristics on Shareholders Assessment of Risk for Small and Large Firms: Evidence from Pakistan. International Journal of Economics and Financial Issues, 6(2), 596-606.

Ocasio, W. (1997). Towards an attention-based view of the firm. Strategic Management Journal,18(1),187-206.https://doi.org/10.1002/(SICI)1097-0266(199707)18:1+<187::AID-S MJ936>3.3.CO;2-B

Parasuraman, R. (1998). The attentive brain (pp. 3-15). Cambridge: MA: Mit Press.

Peeters, C., \& Potterie, B. (2006). Innovation strategy and the patenting behavior of firms. Journal of Evolutionary Economics, 16(1-2), 109-135. https://doi.org/10.1007/s00191-005-0010-4

Tan, J. (2001). Innovation and risk-taking in a transitional economy: A comparative study of Chinese managers and entrepreneurs. Journal of Business Venturing, 16(4). https://doi.org/10.1016/S0883-9026(99)00056-7

Thomas, A. (1988). Does leadership make a difference to organizational performance?. Administrative Science Quarterly, 33(3), 388-400. https://doi.org/10.2307/2392715

Tuggle, C. S., Sirmon, D. G., Reutzel, C. R., ... Leonard. (2010). Commanding board of director attention: Investigating how organizational performance and CEO duality affect board members' attention to monitoring. Strategic Management Journal, 31(9), 946-968. https://doi.org/10.1002/smj.847

Van de Ven, A. (1986). Central problems in the management of innovation. Management Science, 32(5), 590-607. https://doi.org/10.1287/mnsc.32.5.590

Westphal, J., \& Zajac, E. (1995). Who shall govern? CEO/board power, demographic similarity, and new director selection. Administrative Science Quarterly, 40(1), 60-83. https://doi.org/10.2307/2393700

Wu, S., Levitas, E., \& Priem, R. (2005). CEO tenure and company invention under differing levels of technological dynamism. Academy of Management Journal, 48(5).

Yadav, M., Prabhu, J., \& Chandy, R. (2007). Managing the future: CEO attention and innovation outcomes. Journal of Marketing, 71(4), 84-101. https://doi.org/10.1509/jmkg.71.4.84

Yang, C.-H., \& Kuo, N. (2008). Trade-related influences, foreign intellectual property rights and outbound international patenting. Research Policy, 37(3), 446-459. https://doi.org/10.1016/j.respol.2007.11.008

Yang, J., Chi, J., \& Young, M. (2011). A review of corporate governance in China. Asian-Pacific Economic Literature, $\quad 25(1), \quad$ 15-28. https://doi.org/10.1111/j.1467-8411.2011.01283.x 


\section{Macrothink}

International Journal of Accounting and Financial Reporting ISSN 2162-3082

Yang, J., Liu, H., Gao, S., \& Li, Y. (2012). Technological innovation of firms in China: Past, present, and future. Asian Pacific Journal of Management, 29(3), 819-840. https://doi.org/10.1007/s10490-010-9243-3

Young, G., Stedham, Y., \& Beekun, R. (2000). Boards of directors and the adoption of a CEO performance evaluation process: Agency-and institutional-Theory perspectives. Journal of Management Studies, 37(2), 277-296. https://doi.org/10.1111/1467-6486.00181

\section{Copyright Disclaimer}

Copyright for this article is retained by the author(s), with first publication rights granted to the journal.

This is an open-access article distributed under the terms and conditions of the Creative Commons Attribution license (http://creativecommons.org/licenses/by/4.0/) 